\title{
Community-Based Settlements Regularization: Lessons for Scaling up from Makongo Juu Informal Settlement, Dar es Salaam, Tanzania
}

\section{Joseph Mukasa Lusugga Kironde}

School of Earth Sciences, Real Estate, Business and Informatics (SERBI), Department of Land Management and Valuation, Ardhi University, Dar es Salaam, Tanzania

Email: lusuggakironde@gmail.com

How to cite this paper: Kironde, J. M. L. (2019). Community-Based Settlements Regularization: Lessons for Scaling up from Makongo Juu Informal Settlement, Dar es Salaam, Tanzania. Current Urban Studies, 7, 170-192.

https://doi.org/10.4236/cus.2019.72008

Received: February 26, 2019

Accepted: June 7, 2019

Published: June 10, 2019

Copyright ( 2019 by author(s) and Scientific Research Publishing Inc. This work is licensed under the Creative Commons Attribution International License (CC BY 4.0).

http://creativecommons.org/licenses/by/4.0/

(c) () Open Access

\begin{abstract}
Given the need to scale the regularization of the many informal areas growing rapidly in African cities, this paper presents the experience, from efforts to regularize a mixed household income and mixed land use unplanned area called Makongo Juu in Dar es Salaam City, Tanzania. Realising the need to plan this area, the government prepared a number of land use plans which were however, not accepted by the landowners, asking permission to prepare their own. The first community-based plan of the mid-1990s took long to be approved and was overtaken by events. In 2015 the government tasked land owners to come up with an acceptable land use plan, which landowners, working within a community organization, did, and which was approved in 2017. The strengths of this approach included an acceptance by most of the landowners, who contributed in both cash in kind to the preparation of a land use plan, which, after approval, enabled the surveying of the area and of issuing titles. Weaknesses included failure to consider public goods such as the environment and public spaces. Planned neighbourhood roads, which were in any case, not standard, remained in private hands, uncleared and unsecured. It is concluded that government regulation is necessary, even in the case of a community-based regularization scheme, with enforceable provisions made, for regularization and post-planning transactions.
\end{abstract}

\section{Keywords}

Urbanisation, Community-Based Settlement Regularization, Land Use Regulation, Standards, Titling, Scaling-Up, Environment, Makongo Juu

\section{Introduction}

Rapid urbanization, taking place in a situation where public authorities have all, 
but been unable to provide adequate, affordable, appropriately-located and planned land, has resulted in the prolific growth of unplanned and unregulated neighbourhoods in most cities of Africa, large and small, the latter including the rapidly expanding minor towns and trade centres. This phenomenon has been extensively documented and discussed (UN-Habitat, 2008; Hove, 2013).

The resulting informal settlements have been coming up on all kinds of land, including river valleys and land liable to flooding; from city centre sites to the periphery of the city, densifying slowly over a long period, as landowners, who may have originally held the land for agricultural purposes, subdivide it to meet the demand of land seekers eager to put up shelter for themselves, or for investment.

Developers and occupiers of such land may be overwhelmingly in low-income categories, but it is not uncommon to find middle or high income households owning and developing land in unplanned settlements. Most informal or unplanned areas are therefore of a mixed-income household composition.

Common characteristics of unplanned areas include irregular land development lacking urban infrastructure particularly (land for) standard and networked roads and drains; land for public uses such as that for open spaces, and land for social infrastructure notably schools, health centres and burial grounds. Many too lack adequate services for water, electricity, and waste management.

For sub-Saharan Africa, five or more decades of independence are witnessing informal settlements continuing to grow and to thrive (UN-Habitat, 2018). Public authorities have given up on beliefs of being able to demolish informal areas and planning them anew. As a result, these areas have been left to grow on their own, although some have been the subject of some form of public interventions, which have included providing them with water, electricity, schools or health centres. Some, as in Tanzania, have benefitted from regularization undertakings to improve the security of land tenure for landowners through the issuing of residential licences or certificates of title (Chiwambo, 2017). Others have benefitted from formal upgrading projects undertaken by national governments, or with the support of development partners or NGOs.

In some cases, the move to regularize informal areas has been initiated by the residents themselves (Magigi \& Majani, 2006). Of late, the private sector in Tanzania has been playing an important role in the regularization of informal areas, working hand in hand with communities, local governments and the Ministry of Lands.

This paper examines the recent efforts to regularize an area known as Makongo Juu in the city of Dar es Salaam. Previous moves to plan or regularize the area have been unsuccessful. At one time the Ministry of Lands had ideas to convert Makongo Juu into a Beverly Hills kind of a neighbourhood, but had to back down due to the resistance of residents. There are lessons to take from the latest, largely community-based efforts to regularize Makongo Juu, especially now, given the renewed interests by the public and private sectors, communities and development partners to do something about informal settlements. 


\section{Literature Survey and the Conceptual Framework}

\subsection{Proliferation of Informal Unplanned Settlements}

Between $40 \%$ and $70 \%$ of the population in urban areas in Tanzania lives in informal areas or settlements (URT, 2012a: vii). An informal area can be defined as an area which is urbanized and developed haphazardly and usually outside the general regulation of public authorities; and needs surgical action to bring some law and order into it, in terms of elements of land use planning, provision of some infrastructure, and, to eventually adjudicate and title the land parcels.

According to UN-Habitat (2015), informal settlements are residential areas where:

- inhabitants often have no security of tenure for the land or dwellings they inhabit-for example, they may squat or rent informally;

- neighbourhoods usually lack basic services and city infrastructure;

- housing may not comply with planning and building regulations, and is often situated in geographically and environmentally sensitive areas (see also Brown, 2015).

Going through various literature, a comparison can be made between an area which is planned and that which is not. The latter areas are usually referred to as informal or unplanned areas. We will use these terms, interchangeably.

Table 1 presents a comparison between a planned and an unplanned or informal area. The shortcomings found in unplanned areas may form the basis of regularization.

Table 1. Characteristics of a planned and an unplanned area.

\begin{tabular}{|c|c|c|}
\hline SNo & Planned Area & Unplanned or Informal area \\
\hline 1. & Land is planned and surveyed. & $\begin{array}{l}\text { Land is in most cases unplanned and unsurveyed though some } \\
\text { lots may be sporadically surveyed. }\end{array}$ \\
\hline 2. & Land is legally occupied. & Land may be occupied informally, or invaded or squatted upon. \\
\hline 3. & Has regularly shaped land lots. & Has irregularly shaped land lots. \\
\hline 4. & There is little or no land subdivision after approval of the survey plan. & Uncontrolled land subdivision continues all the time. \\
\hline 5. & $\begin{array}{l}\text { Has land for infrastructure such as roads and drains. This } \\
\text { infrastructure may be in place or will in the long-run be in place. }\end{array}$ & $\begin{array}{l}\text { Has no land for infrastructure. May have non-standard and } \\
\text { windery roads, or no roads at all, and most times, no drains. }\end{array}$ \\
\hline 6. & All land lots are planned to be accessible by standard roads. & $\begin{array}{l}\text { Some lots may not be accessible by road. Access may be by way of } \\
\text { narrow paths. }\end{array}$ \\
\hline 7. & $\begin{array}{l}\text { Land is set aside for social infrastructure such as schools, health } \\
\text { centres, play grounds, cemeteries, gardens, markets, religious } \\
\text { institutions and so forth. }\end{array}$ & There is usually, no, or inadequate land for social infrastructure. \\
\hline 8. & $\begin{array}{l}\text { Development control can be enforced. Land developers are required to } \\
\text { conform to some standards, procedures and regulations. }\end{array}$ & $\begin{array}{l}\text { No development control. One's entrance may be opening into } \\
\text { another's toilet. }\end{array}$ \\
\hline 9. & Levies such as land rent or property tax may be charged. & Many times government levies are not charged. \\
\hline 10. & $\begin{array}{l}\text { Have advantages in terms of security and less vulnerability to fire and } \\
\text { flood hazards. }\end{array}$ & $\begin{array}{l}\text { Exposed to higher levels of vulnerability in terms of insecurity } \\
\text { (including eviction and theft), fire, floods and environmental } \\
\text { pollution hazards. }\end{array}$ \\
\hline
\end{tabular}

Source: Author's compilation. 
According to URT (2013) there are, in urban Tanzania, unplanned human settlements sometimes known as informal settlements, which usually have inadequate or lack modern and basic socio-economic services such as roads, water supply, electricity, solid waste services, and sewerage and drainage systems. These are inhabited by low-income earners, at times characterized by large household sizes.

A recent study (Michaels et al., 2017) comparing sites and services projects implemented in seven Tanzania cities in the 1970s/80s found that those areas that were provided with infrastructure right from the start (de novo) developed better housing that those that were not so provided, but were later on upgraded. Specifically, de novo neighborhoods are more orderly and their buildings have larger footprint areas and are more likely to have multiple stories, as well as connections to electricity and water, basic sanitation and access to roads. These had a markedly better residential quality than upgraded areas. Moreover, land values were higher in de novo areas.

\subsection{Challenges Affecting the Provision of Planned Land for Orderly Urban Development}

Many studies have discussed the failure of public authorities to provide land for planned development and to enforce development conditions in cities of developing countries (see for example, Gwaleba, 2018; and Hove, 2013). Several reasons have been put forward. One is the sheer rate of urban growth, which is phenomenal in many cases, as people leave rural areas to join the burgeoning urban areas. Two, public authorities have inadequate resources to manage urban development. Three, there are major governance shortcomings including weak and under-resourced urban authorities; centralization, in the central government or its agencies, of most powers related to local revenue raising, and land use planning; poor or non-existent community engagement; and institutional overlaps between local governments and central government; institutional overlaps between local governments and central government agencies; political expediency; and sometimes, corruption. Four, is the inappropriate regulatory framework, which tends to sideline land users or occupiers, particularly those who are poor; and, in fifth place, is the large possibility of getting and developing land informally (Payne \& Majale, 2004). It needs to be pointed out as well that, in some cases, informal areas grow outside city boundaries but later get engulfed by urban expansion. As will be shown in the case of Makongo Juu, city expansion engulfed a settlement earlier on earmarked for agricultural use.

\subsection{The Concept of a Tripartite Relationship Fuelling the Growth of Informal Settlements}

We can therefore talk of a regime of demand and supply for urban land, which is largely in private hands; and a regulatory system, which is nestled in the public sector. The latter has failed to cope with the requirements for accommodating 
rapid urban growth, whether in terms of providing planned land, or regulating the informal providers of land.

One can thus hypothesize on the existence of a tripartite relationship leading to the growth of unplanned areas, hand in hand with rapid urban growth: the high demand for land; unregulated supply of land and the lack of, or in inappropriate intervention or regulation, by public authorities (Figure 1).

Access to land in actual, or in what becomes, informal settlements, may be relatively cheap or convenient for land seekers-especially those in low income brackets-in terms of costs and, sometimes, location vis a vis their economic and social needs. The fact that land in informal areas may not have development and ownership covenants, may be further incentive for households to acquire it. On the other hand, planned land is difficult and expensive to get; especially for the poor, and it is also many times badly located vis a vis economic and social activities (Kironde, 1995). This is particularly so, for newly-planned neighbourhoods which tend to be at the periphery of urban areas, far from current social and economic hubs.

\subsection{Failure of Unregulated Land Markets}

When land is developed without public intervention, the resulting land use mosaic reflects what in theory has been demonstrated as the failure of the land market. Individual actors maximize private interests leaving out public interests, which are of benefit for all. The resultant land use pattern will lack land for public uses (such as roads, open spaces), it will suffer from harmful externalities

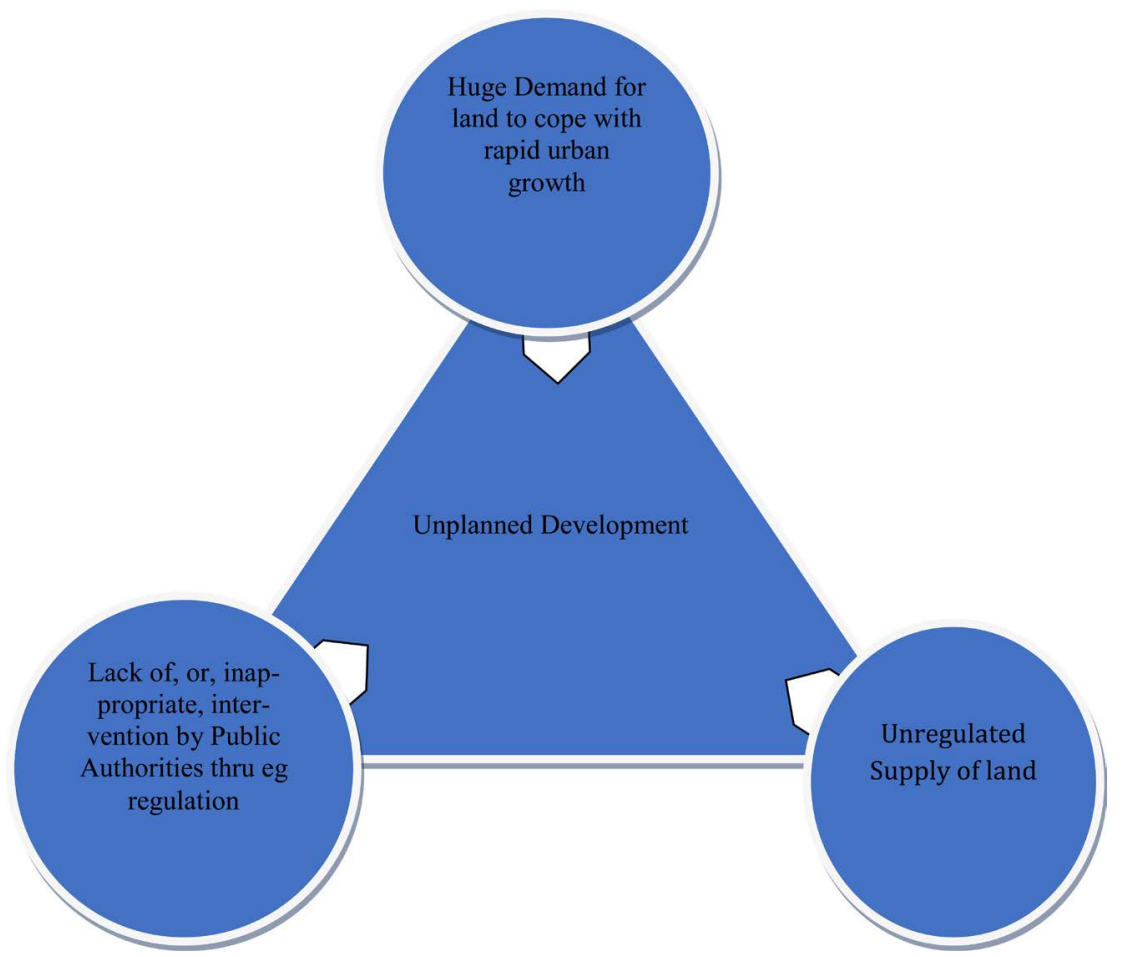

Figure 1. Tripartite relationship fuelling the growth of informal urban neighbourhoods. 
(such as incompatible land uses); and it may not render itself to economic efficiency. Land values, for example, may remain locked up in the land, not being realized or enjoyed by economic actors, due to lack of roads to access what may be the relatively good quality and expensive properties. Public intervention is in part, aimed at smoothening the working of the land markets by providing goods and services with public good characteristics, and dealing with externalities (Cheshire \& Vermuelen, 2009).

\subsection{Understanding Settlement Regularization}

Regularization may be seen as the official intervention in an unplanned or informal area to effect some land use changes, ascertain land parcel boundaries and land ownership and issuing of land ownership documents.

This is opposed to land use planning which is done on a greenfield or over minimally occupied area, usually in peri-urban areas, where existing residents can be removed (e.g. through compensation) and the area planned with little hindrances. The land use plan contains all essential land use requirements and (eventually) land-owners are given a certificate of title to land.

Regularization may also be differentiated from upgrading. The latter is a term used in the 1960s through to the late 1990s to denote improvement undertaken in an unplanned neighbourhood, such as improving roads and drains. Regularization may involve the elements of upgrading, but ending up with land adjudication, titling and/or registration.

In the Tanzanian Land Act 1999, regularization is seen in terms of facilitating the recording, adjudication, classification and registration of the occupation and use of land by those persons living and working in an area. This sees the process more as that of official recognition and documenting of landowners, as opposed to land use planning. However, the Urban Planning Act 2007 requires that a regularization scheme shall include a planning scheme. This therefore, refers to a land use plan.

Nevertheless, regularising an area once it has developed informally is usually difficult. There may be need to acquire land eg for roads and social infrastructure. This will be expensive for public authorities, in terms of compensation, but also difficult to implement as land owners put up resistance. The fact that an informal neighbourhood that gets planned may realise higher land values, is usually not appealing to landowners, who tend to adopt a "not-an-inch-of-my-land-is-to-be-lost" attitude. This is what in part took place in Makongo Juu.

\subsection{Aspects of Settlements Upgrading and Regularization in Dar es Salaam}

During the first decade of Independence (1961-1971), officials and politicians spoke against the continued growth of informal settlements in Dar es Salaam. In the 1968 Dar es Salaam Master Plan for example, a tough policy was advocated against unplanned development. The draconian measures proposed included the 
employment of enforcement officers, the outright removal of emergent squatter areas and all developments inconsistent with the Master Plan, and the non-payment of compensation for disturbance to, and non-resettlement of, the squatters thus cleared (Armstrong, 1987). However, such measures were not implemented. In the subsequent 1978 Dar es Salaam Master Plan, squatters (i.e. those living in informal areas) were to be accommodated (as opposed to their removal), as was housing constructed in local materials. As a result, all areas that were then squatted upon, were zoned residential (Armstrong, 1987).

The World Bank financed sites and services projects of the 1970s/1980s included a large element of squatter areas upgrading (Kulaba, 1985). Indeed, the last two decades or so have seen both the government and development partners focusing on some kind of informal areas upgrading.

In the early 1990s, the government admitted that the non-availability of unoccupied land within urban areas had emerged as a major constraint for planned urban development: "In many of the urban centres, most of the unplanned areas have been squatted upon and the compensation is beyond the means of the government" (URT, 1992: p. 157).

The National Land Policy of 1995 put government policy clearly: "Residents in unplanned areas shall have their rights recorded and maintained by the relevant land allocating authority and that record will be registered" (URT, 1995: p. 19).

Under the banner of the Environmental Planning and Management (EPM), based on the Sustainable Dar es Salaam Project of the 1990s, Dar es Salaam saw the infrastructure of a number of neighbourhoods upgraded, using the community-based approach. Notable among these areas was the neighbourhood of Hanna Nassif, one of the informal settlements that prior to 1996, suffered from lack of basic community services including storm water drains, and as a result suffered frequent floods. The neighbourhood was regularised and served as a model for many other informal settlements (Lupala et al., 1997).

The National Human Settlements Development Policy 2000 (URT, 2000) made a policy statement that: "Unplanned and unservices settlements shall be upgraded by their inhabitants through CBOs and NGOs, with the government playing a facilitating role" (p. 26).

The National Strategy for Growth and Poverty Reduction noted with concern the rapid increase in unplanned settlements:

"The rise in unplanned settlements and crime remain a challenge to urban planning. These strain the government capacity to provide adequate security and social services. Settlements development, land surveying, propagation of simple construction technologies for affordable housing, urban waste or environmental management and slum upgrading stand out as other key challenges. Regularization and titling of land is expected to facilitate residents use of their land and property thereon (dead capital) as collateral with which they may obtain credit from banks and building societies for socio-economic investment" (URT, 2005: p. 7). 
Informal areas were now seen as having the potential, through titling, of being converted into "live capital", from the "dead capital" which they were considered to be before (De Soto, 2000). Titled land could be used to fight poverty among households.

The Community Infrastructure Upgrading Programme (CIUP) (2004-2013) whose objectives were to alleviate poverty and improve the standard of living of low income communities by improving access to infrastructure services (roads, drains, water supply, solid waste facilities, public toilets, and street lighting) using community participation, and in process, enhance the communities' ability to plan and maintain in infrastructure, saw 31 neighbourhoods in Dar es Salaam upgraded. This involved 1000 hectares and benefitted 420,000 households. The project was jointly financed by the World Bank IDA, the Government of Tanzania, the Dar es Salaam City Council and Dar es Salaam municipalities and the beneficiary communities (Mazwile, 2013).

Although the CIUP had no element of improving security of tenure for land owners in the sense of issuing ownership documents, a subsequent programme proposed by the Ministry of Lands was supposed to take care of this, by issuing residential licences and full titles to land owners in upgraded areas (URT, 2012b).

Kusiluka and Chiwambo (2018: p. 1) talk of informal settlements regularization programmes in Tanzania which have largely focused on issuing formal ownership documents such as land titles and residential licenses to property owners. According to them, in Tanzania, most of the informal settlements regularization initiatives are carried out under specific programmes executed through several small projects in different parts of the country. The projects entail planning, surveying, and registering landowners and giving them land titles after paying statutory fees and charges.

The general attitude towards informal urban areas, at both the international and national levels is, therefore, no longer to demolish them but to regularize them. The question has always been how. Makongo Juu provides useful experience.

\section{Methodology}

This paper is based on a study to evaluate the latest efforts to regularize the Makongo Juu area on the basis of a community-based approach, which however, saw highly limited intervention or regulation by public authorities; to restate the achievements of this approach; and to point out the challenges.

\subsection{Objectives of the Study}

The objective of the study was to be able to show what approaches can be used and what precautions must be undertaken during settlement regularization, since, given the widespread existence of urban informal settlements, scaling up regularization is imperative, if inroads must be made into having orderly cities in Tanzania and elsewhere. 
It is intended to show that public authorities have a cardinal duty to intervene in the operations of the land markets through appropriate regulation and procedures. The question is no longer whether to intervene or not to intervene, but to how to intervene. Regularization based on community wishes, while desirable, has its own limitations. This calls for a compromise between a top-down approach, and a community-based approach.

It is hypothesized that the near-complete absence of state intervention in settlement regularization results into a land-use mosaic which falls far short of the need to take care of the public good.

\subsection{Study Methods}

The information on the Makongo Juu area was obtained from a number of approaches. One, is participant observation, as an owner and developer of land in the area since 1985. Two, various studies that have been carried out on Makongo have been analysed. These include Burra (2004, 2005), Moyo (2006), Kalugila (2013), Layson \& Nankai (2014), and, Lerise \& Silayo (2017). The third approach was through participation in a number of missions on the development of Dar es Salaam (e.g. from the World Bank) that have included Makongo Juu in their itinerary-missions that elicited a lot of information on the area from officials and stakeholders; and, four, interviews and discussions with Makongo Community leaders and a number of land owners. Interviews and discussions were also carried out with public authorities responsible for settlements regularization in the Ministry of Lands and in the Kinondoni Municipal Council of the City of Dar es Salaam.

Those interviewed include: the Mtaa chairperson; the KAUMAMA Chairman; a registered town planner, two registered surveyors, and a financial expert, all connected with KAUMAMA; a land officer and a senior town planner in the Ministry of Lands; a town planner and land officer at Kinondoni Municipal Council; a senior academic; and 10 landowners in Makongo Juu. The study is therefore mainly qualitative.

\subsection{Introduction to the Makongo Juu Settlement}

Makongo Juu is some 17 kilometres from the Dar es Salaam City Centre (Figure 2 ), on raised ground and was usually referred to, in past literature, as being to the periphery of the City, although this is no longer the case. The topography is characterized by numerous valleys and rivulets, a good number of these emptying into the Mbezi River, or the Mlalakuwa River.

Burra (2004) and Kalugila (2013) give a historical account of Makongo Juu, as having been a sisal estate, which was left in abandonment when sisal farming collapsed in the 1950s. Makongo Juu includes land belonging to the then Colito, now, Lugalo, Barracks. During the 1950s and 1960s, land was largely obtained through clearing as much bush as possible, and much of the area was put to agriculture. Land seekers, including middle to high income households, continued to 


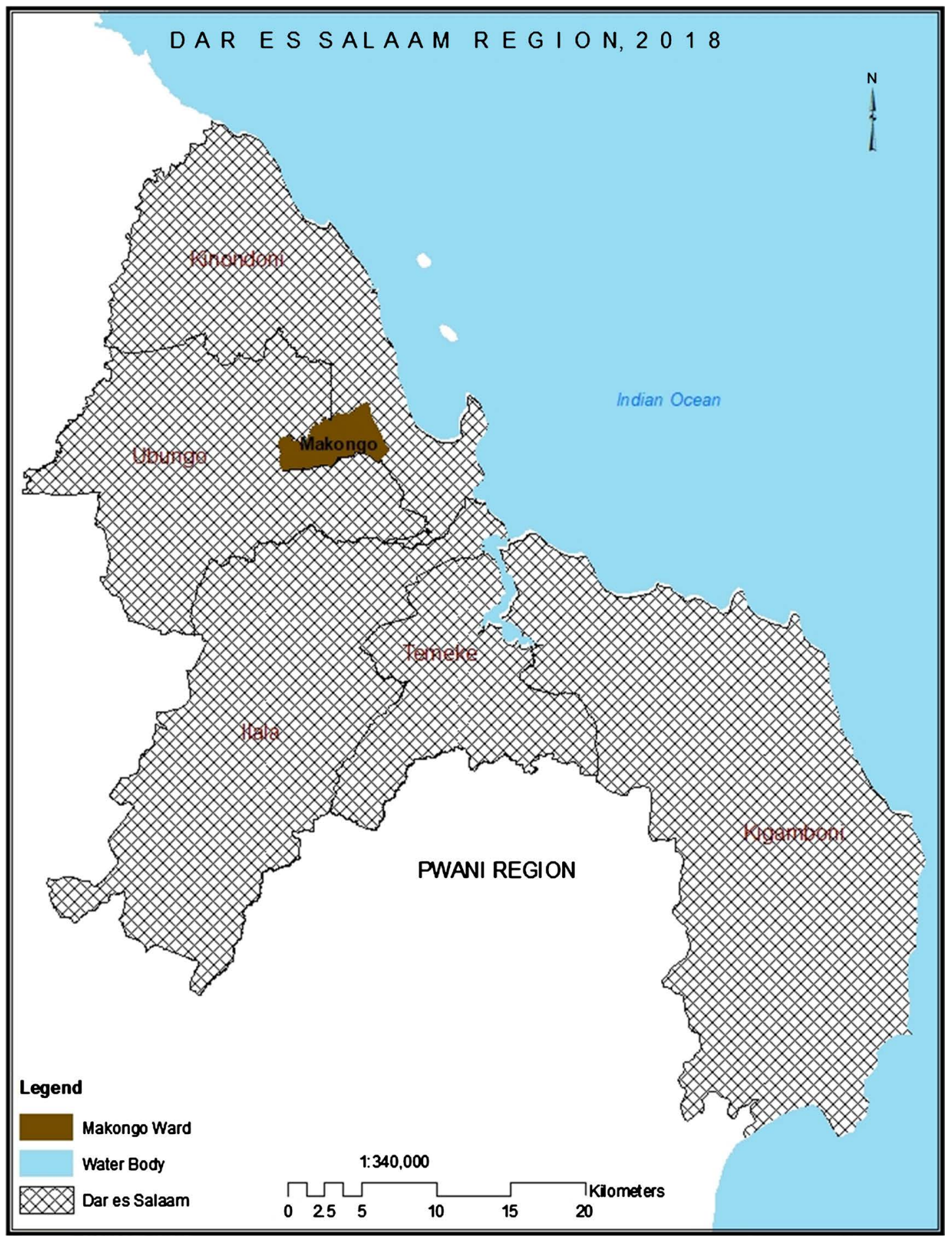

Figure 2. Dar es Salaam, the location of Makongo Juu settlement.

flock to Makongo Juu, acquiring land mainly through purchase, with land parcels becoming smaller and smaller over time, though many of the better-off households retained large pieces of land.

Residents of Makongo Juu are a mixed bag in terms of social status: ranging from the rank-and-file to those whose names carry heavy accolades including 
(former) Ministers, Ambassadors, top-ranking civil servants and politicians, academics, professionals and businessmen. They come from various parts of Tanzania and are a mixture of all faiths and incomes. To a great extent, this reflects what Tanzania has been striving to create over the years: a non-segregated society, where people can live with one another peacefully, despite their differences.

The majority of Makongo Juu landowners, much as they are among the enlightened, are keen to jealously keep every inch of their land to themselves. The argument of having a little less land which has higher values (from a planned and services neighbourhood) does not click a chord. This "not-an-inch" view, was held by many landowners talked to. This is demonstrated by the fact that all those who can, quickly fence their land with solid walls.

Makongo Juu is within the Kinondoni Municipality, and in terms of local government structure, there is a Makongo Ward comprising of four mitaa, that is: Makongo, Mlalakuwa, Changanyikeni and Mbuyuni (Figure 3). The settlement occupies 1500 acres with an estimated population (2014) of 17,000 inhabitants (Layson \& Nankai, 2014). The settlement continues to densify.

M A K O $N$ N G $O$ O W A R R

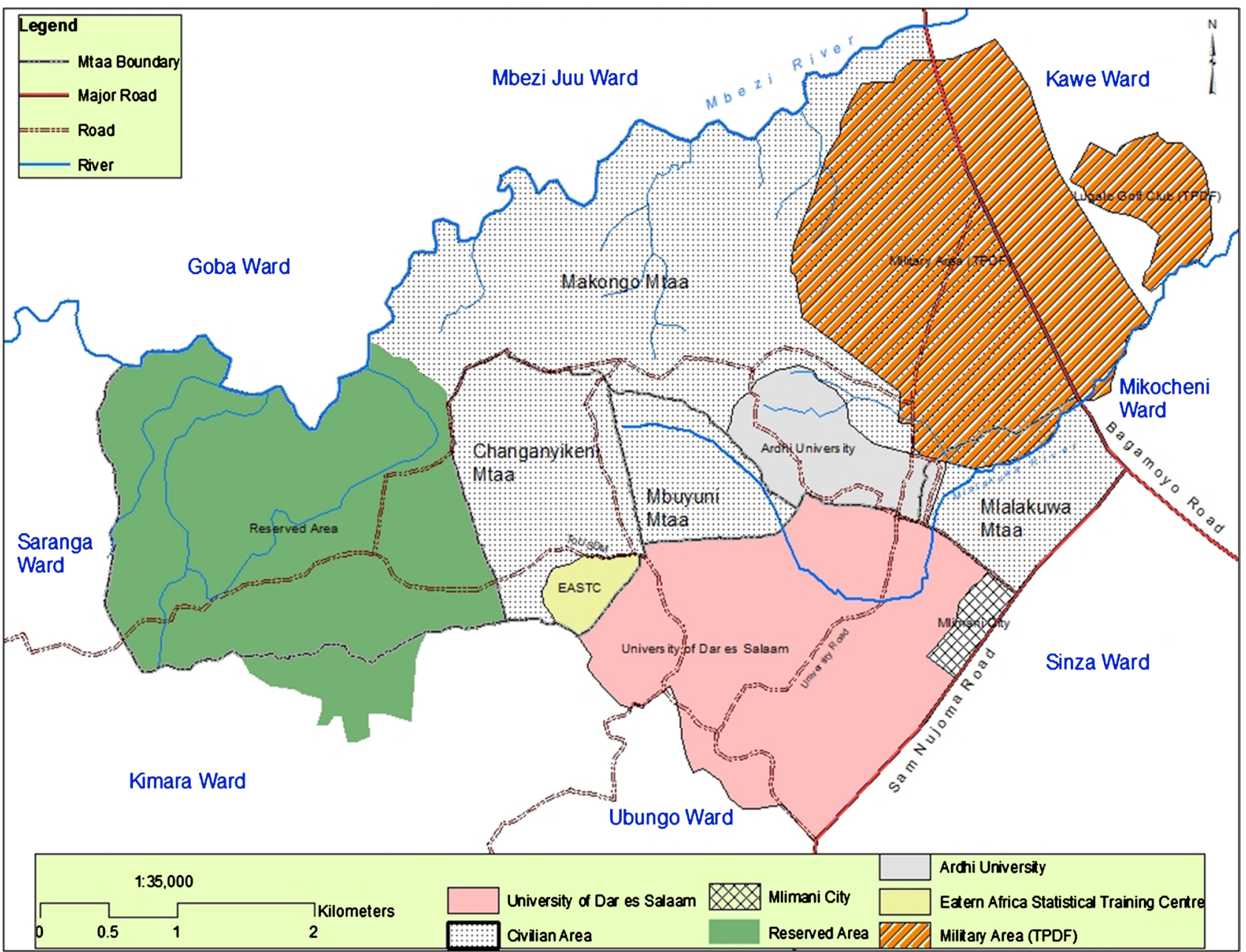

Figure 3. Makongo Juu, administration and neighbourhood. 
Both the Government and landowners have always realized the need to have Makongo Juu developing as a planned area, but, public action has always come too late, or it has never been implemented or it was not accepted by land owners to guide land development (Figure 4).

\section{Findings}

\subsection{Phases in the Land-Use Planning Initiatives for Makongo Juu Settlement}

Makongo Juu has gone through a number of phases, from being agricultural land outside city boundaries, to a coveted mixed use but mainly residential area, which has attracted government and scholarly attention in recent years.

Table 2 summarises key milestones in the land use planning of Makongo Juu from the 1950s to the present.

\subsection{Lessons from the Regularization of Makongo Juu Settlement}

There are both positive lessons as well as challenges to be gleaned from the experience of regularizing Makongo Juu which could inform any future public action to regularize informal settlements in Tanzania and elsewhere. Given that the majority of urban residents in the country live in informal areas, scale regularization of such areas is urgently required, if Tanzania has to attain a middle-income status as envisaged by the country's Vision 2025.

\subsubsection{Achievements of the Community-Based Approach in the Regularization of Makongo Juu Settlement}

After the public refusal to accept the 2012 land use plans for Makongo Juu, the Minister for Lands declared in 2015 that the Ministry was no longer interested in implementing its proposed land use plan for the area, but tasked the landowners

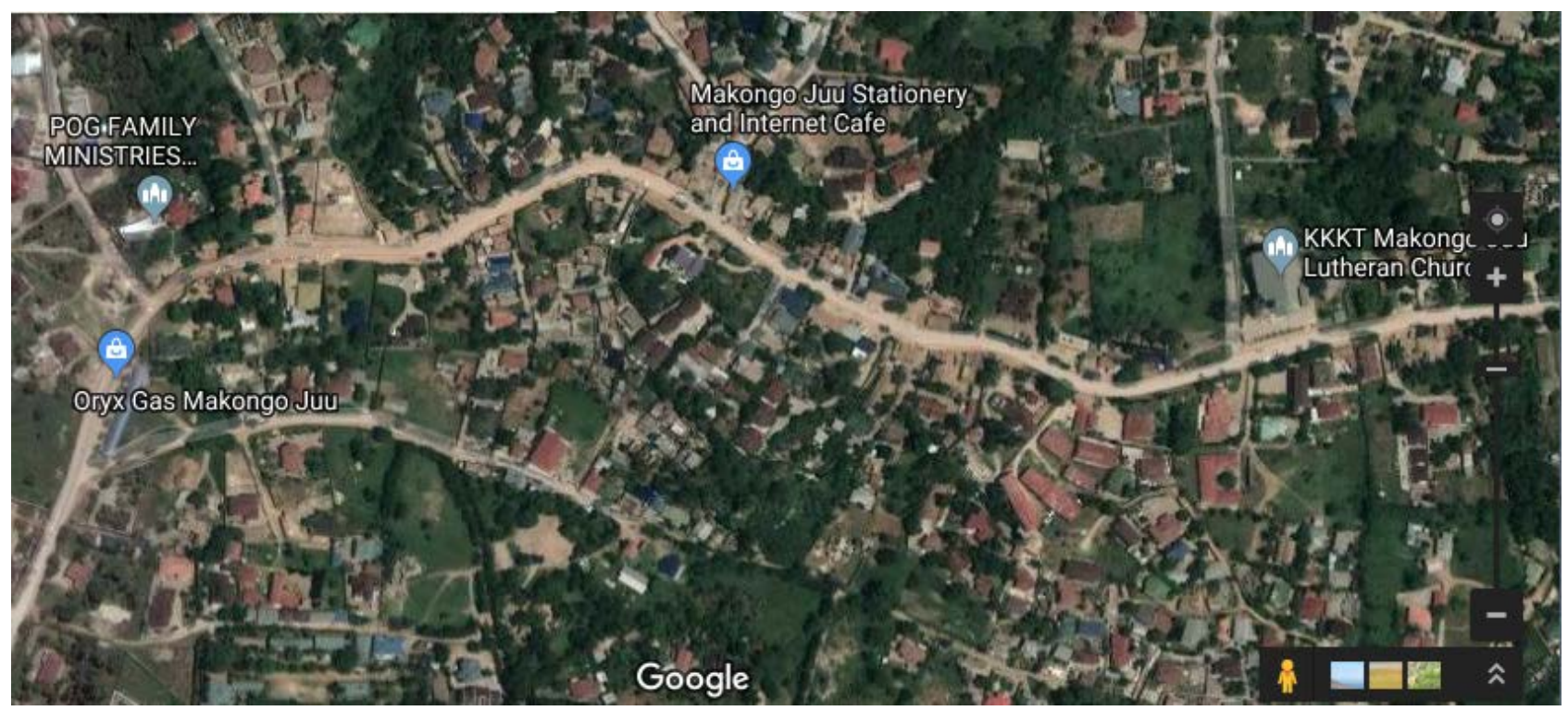

Figure 4. Part of Makongo Juu. Note dense development as well as large land lots. Source: Google Earth. 
Table 2. Key landmarks in the land use planning initiatives of Makongo Juu settlement.

\begin{tabular}{|c|c|c|}
\hline SNo & Date & Event \\
\hline 1. & 1950 s & $\begin{array}{l}\text { Makongo is a Greek-owned sisal estate which collapsed in the 1950s and the area started to be occupied haphazardly by } \\
\text { former workers in the sisal estate and by land seekers mainly for agriculture. }\end{array}$ \\
\hline 2. & 1968 & $\begin{array}{l}1968 \text { Dar Master Plan designates Makongo Juu a greenbelt to be put to non-urban uses including agriculture. Overall, } 1968 \\
\text { Plan not implemented. Informal occupation of land continues. }\end{array}$ \\
\hline 3. & 1974-76 & $\begin{array}{l}\text { National Villagisation Programme. Makongo Juu used as a resettlement village and land allocation now effected by local } \\
\text { leaders. No land use plan for the area. }\end{array}$ \\
\hline 4. & 1979 & 1979 Dar es Salaam Master plan upholds Makongo Juu's status as a greenbelt. Informal land transactions continue unabated. \\
\hline 5. & 1985 & $\begin{array}{l}\text { Makongo changed to a planning (i.e. an urban) area whose development was to be regulated, but no serious land use } \\
\text { planning action undertaken. Informal occupation and development of land continues. }\end{array}$ \\
\hline 6. & 1991 & $\begin{array}{l}\text { Ministry of Lands prepares a detailed land use plan for Makongo Juu, which people reject and request the Minister to allow } \\
\text { them to prepare their own, a request which the Minister granted in } 1992 \text { (URT, 1991). }\end{array}$ \\
\hline 7. & 1992 & $\begin{array}{l}\text { Makongo Juu residents hire a consultant to prepare a land use plan for the area suitable for residents' needs as well as meeting } \\
\text { the necessary requirements by public authorities. A Draft Plan ready in } 1995 \text { but keeps on being ping-ponged between local } \\
\text { government authorities/Ministry of Lands and the community till } 1999 \text { when a final draft was submitted but approval has } \\
\text { never been given. Unplanned land development continued unabated. Some parcels got surveyed and even titled, but without } \\
\text { a general land use framework for the whole settlement. }\end{array}$ \\
\hline 8. & 1995 & $\begin{array}{l}\text { Makongo Juu Development Association (MAJUDEA) formed, whose aim was to mobilize members and resources to } \\
\text { contribute towards infrastructure, services, land use planning and environmental management. This period saw the } \\
\text { formation of many area based development associations in the country in general and in Dar es Salaam in particular, to } \\
\text { mobilize resources to fill in the gap left by public authorities. By } 2012 \text { however, MAJUDEA was no longer functioning. }\end{array}$ \\
\hline 9. & 2012 & $\begin{array}{l}\text { Ministry of Lands proposed another detailed land use plan to convert Makongo Juu into a Beverly Hills of some sorts, } \\
\text { according to the Minister. The plan included a financial facility whereby the Ministry would obtain a commercial loan to be } \\
\text { repaid by landowners through a Betterment Levy. The Minister was no doubt riding on the wave of the success of the } 20,000 \\
\text { Plots Project (Kironde, 2011, 2015). Both the proposed detailed land use plan, which implied demolitions (and worries about } \\
\text { compensation), as well as the levy, scared the landowners who marshaled public opinion against it. }\end{array}$ \\
\hline 10. & 2015 & $\begin{array}{l}\text { A new Minister for Lands meets Makongo Juu landowners and grants them the freedom to proceed with their own land use } \\
\text { plan. }\end{array}$ \\
\hline 11. & 2015 & $\begin{array}{l}\text { A } 20 \text {-member local formalization committee known as Kamati ya Uboreshaji wa Makazi ya Makongo Juu (KAUMAMA) was } \\
\text { elected to work with Mtaa government, the land owners, the Ministry of Lands and the Kinondoni Municipal Council, to } \\
\text { mobilize resources, and to ensure that the settlement is planned and land parcels titled, in a participatory manner. }\end{array}$ \\
\hline 12. & 2016 & $\begin{array}{l}\text { Proposed town planning layouts endorsed by landholders, followed by scrutiny and endorsement by the Kinondoni } \\
\text { Municipal Council and the Regional Administration. }\end{array}$ \\
\hline 13. & 2017 & Land use layout plans for Makongo Juu approved by Ministry of Lands. \\
\hline 14. & 2018 & $\begin{array}{l}\text { KAUMAMA hands over planned Makongo Juu land use layouts and other data to the Mtaa Government for continued } \\
\text { development control and land management. }\end{array}$ \\
\hline
\end{tabular}

Based on Burra (2004), Kalugila (2013) and Lerise \& Silayo (2017), and interview with KAUMAMA Secretary.

to come up with an alternative plan. To some extent, this ministerial position may have come about, as a result of political changes which included a new Minister for Lands. Given the odds against the Ministerial plan, and taking into consideration the previous land use plans on Makongo Juu which were not accepted, allowing the public to come up with their own plan seemed to ensure a way forward. 
Besides, there was no chance that the Ministry would mobilize the resources to pay compensation, should it decide to stick to implementing its own layout. Lack of resources for paying compensation had already derailed the creation of the Kigamboni New City across the Dar es Salaam harbour. So, if landowners were interested in regularizing themselves, it was wise to let them go ahead. Moreover, the Government's attitude was tilting in favour of titling and maximizing revenue collection, rather than emphasizing proper land use planning standards.

Important statistics on Makongo Juu as at the end of September 2018 were as shown in Table 3.

After its election, KAUMAMA formed four sub-committees, namely: Finance and communications, Preparation of detailed layout plan, Cadastral surveying and titling, and Legal and administrative procedures compliance. The policy and final decision-making level are the public meetings that include landholders and the KAUMAMA. The Mtaa Chairman organizes and chairs the public meetings and the Executive Officer is the secretary (Lerise \& Silayo, 2017: p. 4).

Among the important achievements realised by KAUMAMA are the following:

1) Identification of land owners and their land parcels (adjudication). The parcels varied in size, shape and tenure status. A number had certificates of title. Others had residential licences and yet others had only sale agreements. Some 3200 parcels were identified. Public meetings were called to enable owners to verify their land parcels. Their views and objections were recorded and many were addressed.

2) Financial arrangements, to meet the costs of layout plan preparation, cadastral surveying and land titling were agreed upon by the land owners. These were

Table 3. Important statistics on Makongo Juu settlement regularization, September 2018.

\begin{tabular}{cccc}
\hline SNo & Description & Figures & Remarks \\
\hline 1. & Population as per 2012 census & 15,729 & \\
2. & Estimated Population 2018 & 18,000 & \\
3. & Land area (hectares) & 541 & \\
4. & Number of Land parcels in the settlement & 3200 & \\
5. & Number of Plots in approved town planning drawing & 2917 & \\
6. & Number of Plots in approved survey plans & 2810 & \\
7. & Number of Plots for which KAUMAMA costs have been & 1143 & approved layout \\
& fully paid & & \\
8. & Number of Plots for which titling fee have been paid & 267 & \\
9. & including premium & 159 & \\
10. & Total monetary contribution by landholders (TZS) & $604,900,000$ & US\$ 274,954.5 \\
11. & Total Expenditure (TZS) & $582,900,000$ & US\$264,954.5 \\
\hline
\end{tabular}

Source: Office of Mtaa Makongo September 2018. TZS = Tanzania Shillings. 
fixed at TZS 450,000 (USD 205.5) for parcels without titles; and TZS 225,000 (USD 102.3) for parcels that were already titled. These however do not include the costs of obtaining the title levied by the Ministry of Lands. At the time of the handover, some TZS 605,900,000/= (USD 275,409) had been raised. This is an indication of the trust that the people had in the community approach.

3) Two experienced and registered Town Planners developed a land use plan, changing boundaries here and there to ensure that each land parcel has road access since it is not possible to issue a title over land that is inaccessible by road. Some $35,000 \mathrm{~m}^{2}$ of land space, worthy billions of shillings, was contributed by the owners for roads. Access roads from 3 to 8 metres wide were "acquired" without compensation. In total, 110 pieces of roads of various lengths moved from private to public land.

4) The planners were flexible on road hierarch, standards and plot sizes and shapes. According to Lerise and Silayo (2017: p. 7): “There were situations where taking landholders interests into account, required flexibility in procedures and upholding standards. For instance, standards of plot sizes and widths of access roads were adjusted and adopted to the local conditions without undermining their functionality. Where a plot was too small (below $90 \mathrm{~m}^{2}$ ) and thus difficult to provide access to each individual plot, the Unit Title approach was recommended". The conceptual plan was presented to the people in a public meeting and was approved.

5) Comments were received from the Kinondoni Municipal Council and the Regional Administration; and, in 2017, the layout plan was approved by the Ministry of Lands.

6) As pointed out above, 3200 land parcels were identified. However, 2917 appear on the town planning layout drawing and those approved for surveying are 2910. This is because some parcels within $60 \mathrm{~m}$ of the river Mbezi were left out, as they were on hazard land.

7) On the basis of this layout plan, land surveying was undertaken by a sourced contractor who was paid a total of TZS 275,000,000 (USD 125,000). All parcels were surveyed irrespective of whether one had paid fully or not. Those who had not paid fully were required to do so before going for the land title.

8) The Plan avoided demolition along major roads. Discussions were going on with TANROADS for compensation for those adversely affected and valuation has been undertaken.

9) Land use layout was achieved without resettlement or compensation. Land for roads was granted by owners through negotiations, although this land has not been "secured".

10) As for social services: there is a school and health centre nearby and the army has granted Makongo Juu residents, burial grounds. A commercial area is growing along the main roads. Thus, Makongo Juu was able to ride on public land uses that were in neighbouring areas. According to the KAUMAMA Secretary: "Public open spaces, however, could not be accommodated in the Makongo 
Juu layout plans".

11) While beacons were fixed on the ground, the government is being urged to clear the smaller roads, of existing structures, to grade the roads, so that they can be seen to have moved from private to public hands.

\subsubsection{Challenges Facing Makonjo Juu Settlement despite the Approval of a Land Use Plan for the Area}

Despite the commendable job done by KAUMAMA, a number of challenges can be pointed out. These emanate mainly from the fact that the focus of the regularization was to ensure that as far as possible, current landowners maintain their land, with little or no change; and that they finally get it surveyed and titled. This focus left a number of challenges unaddressed. These include the following:

1) KAUMAMA was unable to address issues of storm water drainage, gullying and environmental degradation. Makongo Juu is suffering from serious gullying and soil erosion putting many properties in danger (Figures 5(a)-(d), photographs taken by the author, February 2019). Erosion is increasing by the day as more and more people clear the surface and put up buildings. The narrow "flexible"

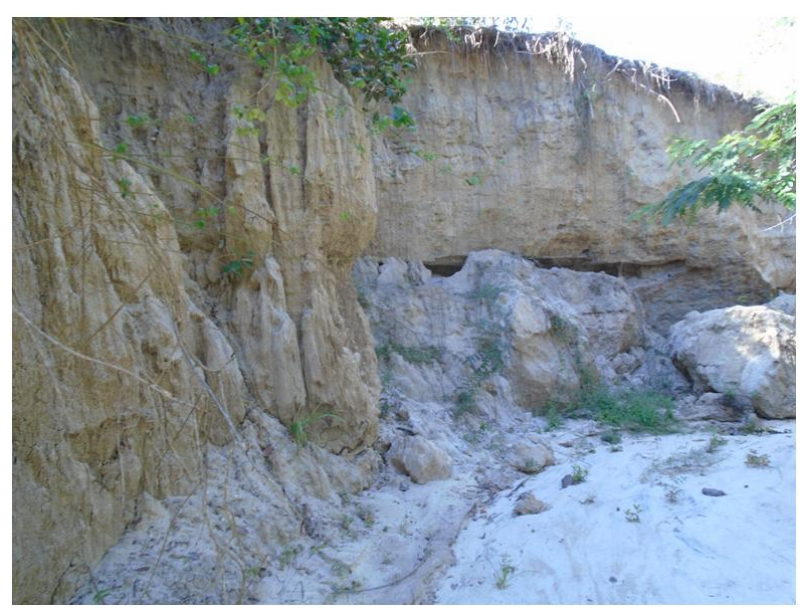

(a)

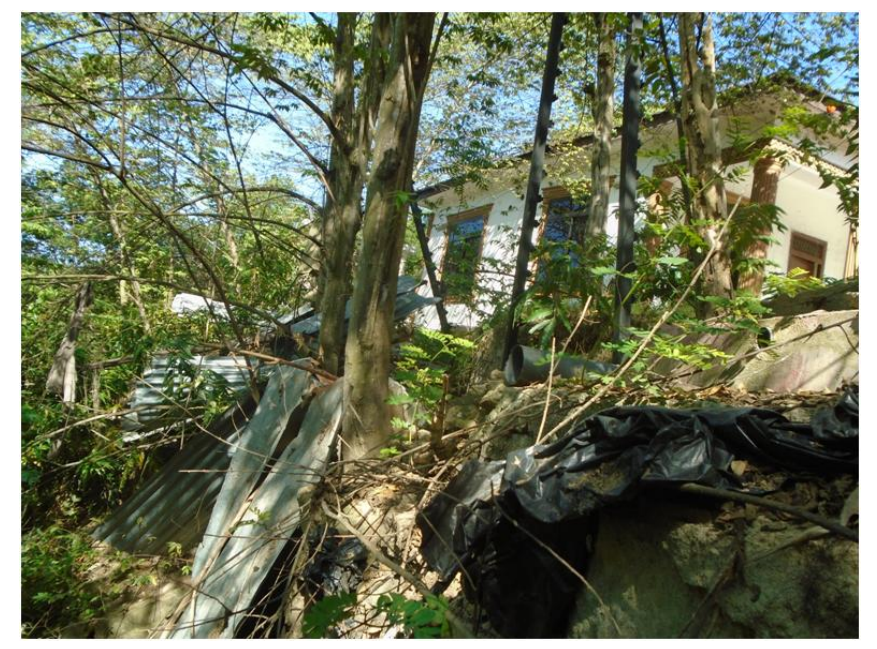

(b) 


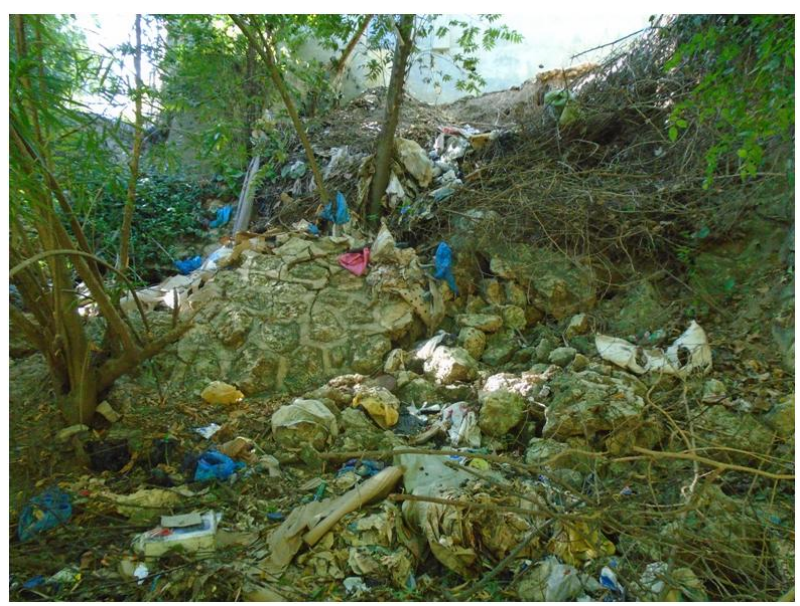

(c)

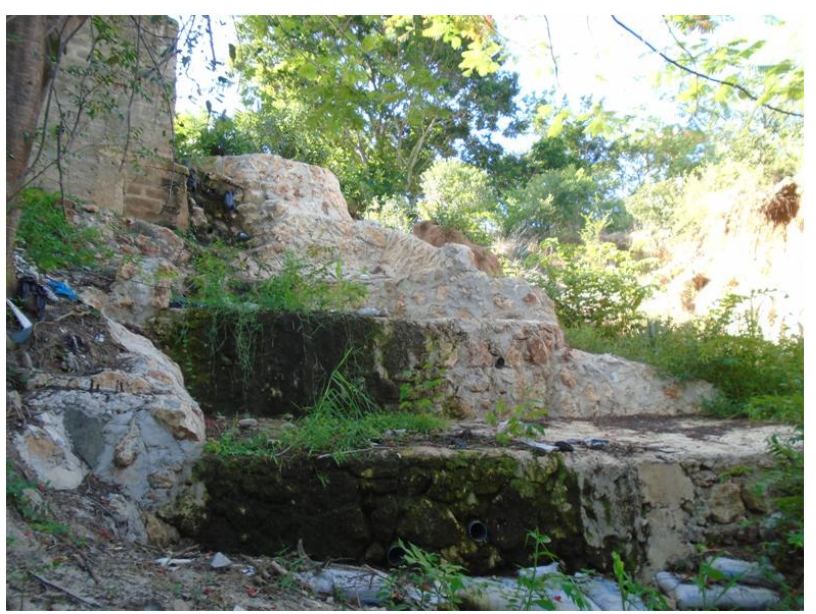

(d)

Figure 5. (a) This stream, a small rivulet in the past, is widening by the day; (b) Ground surrounding house eaten away by erosion. The house may follow; (c) Unsuccessful attempts to contain erosion; (d) Expensive but unsuccessful efforts to contain erosion.

roads can add to this erosion since they have no provisions for drains and they increase surface water velocity. Titling, as an end product, does not cure environmental degradation.

2) Land planned for access roads was negotiated and planned but it was not secured by way of clearing and transferring such land to the public domain. This point was emphasized by the KAUMAMA Secretary in his handover speech. The hope was that the Mtaa government will mobilize resources from the Kinondoni Municipal Council and clear the roads. This, however, is unlikely to happen in the near future. Cash contributions by land owners should have included an element of civil works, such as public way clearance and storm water drains.

3) Many land parcels are not accessible by road (planned or physically existing), in cases for example, where a neighbor refuses to grant a right of way to a neighbour. KAUMAMA proposes a Unit Titles approach, where several owners legally share some common parts. How this would operate is not clear and there 
are no precedents. In some cases however, KAUMAMA admitted failure and decided to leave things as they are i.e. with some landowners not having access, but went ahead and had the land surveyed: "We leave it to the neighbours to sort themselves out", said the surveying contractor, in an interview. This points to the importance of having some legal powers to enforce matters, instead of reliance on persuasion alone.

4) The institutional framework poses a challenge. Land use planning and development control should be in the hands of LGAs. But the Ministry of Lands is also playing an active role overshadowing LGAs. Regularization can realize some success in a situation of strong local governments, which, in Tanzania, need strengthening.

5) Lack of appropriate regulations to address the situation in an area that has developed informally and the ideals of a planned settlement is a serious lacuna. KAUMAMA adopted flexibility by proposing what seemed feasible, but avoided addressing serious challenges. Any form of land use planning must be backed by regulations not intuition. Enforceable regulations can make negotiations with landowners easier.

6) The question of post-survey transactions was left vaguely in the hands of a weak Mtaa government. What happens if landowners subdivide and transfer (part of) their land? Are landowners subjected to development control, now that the neighbourhood is planned and surveyed? These questions were left unanswered.

7) Several properties were left out of the planned land use scheme because they were on what was considered to be hazard land. The owners were not removed so they are continuing to develop their land and will most likely continue to subdivide, creating a slum within Makongo Juu.

8) The Ministry of Lands, despite spending little on Makongo regularization, has come in with conditions to issue titles which involve a series of charges and a premium based on $1 \%$ of the land value, which, as a result of regularization has been calculated by the Chief Valuer as TZS 35,000 per square meter. Land-holders are protesting this, which has now removed the incentive to take the title to land, and presumably, the incentive to pay the rest of KAUMAMA costs.

\subsubsection{Drawing on the Experience of the Community-Based Regularization of Makongo Juu Settlement}

A number of observations can be drawn from the Makongo Juu regularization experience; observations that need to be taken into consideration when contemplating undertaking settlement regularization schemes.

1) Regularization must be based on peoples' trust not top down imposition. There must be implementation arrangements which people trust and identify themselves with. It is highly unlikely that the people of Makongo Juu would have agreed to meet the cost of land use layout preparation and surveying, if arrangements were direct from the Ministry. The cost itself was worked out and agreed at public meetings. As a result, the compliance rate with payment is quite high. By contrast, during the implementation of the CIUP, communities failed to pay the $5 \%$ cost of the project upfront and had it paid by municipalities in the 
hope of recovering the money from property tax.

Arrangements coming in from above are bound to be regarded with suspicion. If land must be acquired, there is always the fear that compensation will be unfair and it will not be paid on time; and there may be hidden agendas for land grabbing. If financial contributions are expected, there needs to be guarantees that the money will not be embezzled. Makongo Juu therefore offers an approach which can be replicated elsewhere.

2) Use of local expertise was an important ingredient in the success of Makongo Juu settlement regularization which added to the confidence which landowners needed. Local professionals who participated actively in preparing and processing the Makongo Juu land use layout plan included: town planners, land surveyors, accountants and administrators. There must be local people, including professionals, who are willing to dedicate their time and expertise to the betterment of their neighbourhood. These will be people who have a stake in the welfare and development of the area.

3) Land use layouts prepared by the Ministry of Lands for Makongo Juu were not accepted by land-holders because they were prepared with little reference to what was on the ground; layouts which substantially altered the properties of the existing land parcels. Besides, they were not prepared with the participation of land-owners whose fate was hazy, should the layouts be enforced. Consideration for scaling up must be based on the existing land-ownership pattern with any proposed changes discussed exhaustively with landowners. The question of compensating those who lose land should not be left out altogether.

4) Land earmarked for public use in a regularized neighbourhood must be secured immediately both legally and physically to avoid the danger of its takeover by former owners or new invaders. For example, roads or open spaces could be cleared, graded, named and gazetted.

5) Appropriate by laws to regulate land use and development in the regularised area must be passed by the community and enforced to regulate private and public behaviors and transactions after the approval of land use plans.

6) In the case of Makongo Juu therefore, it would have been prudent to include, in the community contributions and/or in the regularization activities, the costs for undertaking civil activities like clearing roads; as well as the cost of preparing and approving community by laws to regulate the post-titling development of the regularized neighbourhood and the cost of compensation to those losing land. Landholders must go into some kind of social contract to abide by the approved land use plan.

7) In embarking on settlement regularization, it may be useful to explore the possible application of approaches that have been used successfully in the past or elsewhere. A good example is the land pooling and adjustment approach, which was applied successfully in the 1950s and 1960s to the Upanga area in Dar es Salaam, an area which was rescued from developing into an unplanned are, to the high value area that it is currently (Kironde, 1995). 
8) Public authorities must play an ongoing role in supporting settlement regularization, by prescribing some procedures and enforcing some laws, regulations and standards. In the case of Makongo Juu for example, it may have been useful to legally declare the area to be a regularization area, to develop and enforce appropriate standards to which all must abide. According to one key informant, efforts were made to convince the Ministry of Lands to declare Makongo Juu a regularization area or a special planning area, to no avail.

9) It may as well be necessary to have a minimum area for a regularization scheme in order to have room to accommodate standard neighbourhood land use requirements and to enjoy some economies of scale, which can lower the unit cost of regularization. In the case of Makongo Juu, it was not possible to have land for schools, or health centres. There was no open or recreational space or burial grounds, and reliance had to be made on other neighbourhoods or institutions. Makongo Juu therefore is not self-sufficient in key neighbourhood land uses.

\section{Discussion}

Lerise and Silayo (2017) have but a rosy picture of the future development of Makongo Juu, whose land use layout was prepared with the people and taking into consideration the peoples' interests. They seem to lay hope on the future organized development of Makongo Juu on the Mtaa government whose capacity was somewhat improved through the project.

Nevertheless, there are reasons to be apprehensive. Development control in general, and at local government level in particular, is weak. It is therefore more likely than not that Makongo Juu will develop in the near future as if there was no approved land use plan, since there is no mechanism to enforce it, unless there was a community organization, or a strong local government legally mandated to oversee the future development of the settlement.

Otherwise, the approved land use plan is unlikely to form the basis of future development. The fact that only $39 \%$ of land owners had fully paid KAUMAMA costs, as of September 2019, points to a less enthusiastic community, a situation made worse by the Ministerial requirements before one can obtain a title, which many landowners will find expensive. In many countries, first land registration is free and this is what should the case be for Makongo Juu, but only time will tell whether the Ministry will adopt a different approach.

Those who are keen on titles will brave the situation and take them, but this is likely to be a minority of the landowners in Makongo Juu as the current situation data suggests. As has been pointed out above, even in the past, one could get a title, on the basis of sporadic surveying. At the same time, it has been pointed out time and again that the title is not the optimum indicator of security of tenure, given other relevant circumstances (Moyo, 2006).

The current Ministry of Land's interest in Makongo seems to be collecting land rent, and premium to boost government revenue from every parcel of land in the City of Dar es Salaam. Nevertheless, the government needs to invest in the 
area, not only in terms of capital expenditure (e.g. infrastructure), but also in enforcing some kind of regulations, or standards and not entirely leave these to communities to act alone.

There are existing legal provisions which the government could have relied upon; such as the provisions in the Land Act 1999 (sections 56 - 60) and the Urban Planning Act 2007 with regard to land regularization. These allow the government to declare and area to be a regularization area and, therefore, to have the legal powers to enforce some standards, in close consultations with the community. Indeed the Urban Planning Act (section 23) makes such declaration compulsory: "23.-(1) Any area intended for a scheme of regularization shall be declared as a planning area under this Act".

In the case of Makongo Juu, negotiations were left to the communities alone and Lerise and Silayo (2017) think this a good development since you get a peoples', not a top down land use plan. However, in land use planning, there is the role of the public authorities, given the imperfections of the land markets.

This public sector role is not just approving a proposed land use plan. The essence of public intervention in land markets is, among others, to provide goods and services with public good characteristics; to prevent harmful externalities, to provide merit goods, and so on. It is not to agree with the people but to get them to adhere to some public interest standards. These standards, though, must be "appropriate" to the situation being addressed. The people have to be tweaked into accepting them, using legal authority. The required changes may be minimum but public authorities do not abdicate their duty. In case of Makongo Juu, what was approved does not conform to any standards, which latter possibly need to be developed for future regularization undertakings. Official approval of the Makongo Juu land use plan was fast in comparison to past experience, possibly with the urgent need to collect revenue in mind.

\section{Conclusion}

Property owners in Makongo Juu have demonstrated invaluable efforts to see to it that their area develops as a planned and titled neighbourhood. They opted to do this with minimum public sector intervention. With hindsight however, public authorities had to be there, to flex some muscles and enforce some land use standards for the public good. Indeed titles must be respected and be issued over land that meets basic land use planning standards.

The minimum presence of public authorities and lack of enforceable minimum planning standards means that Makongo Juu may not develop into the Beverly Hills neighbourhood which a former Minister for Lands wanted it to be, but it offers valuable lessons into settlement regularization based on community participation.

\section{Conflicts of Interest}

The author declares no conflicts of interest regarding the publication of this paper. 


\section{References}

Armstrong, A. M. (1987). Master Planning for Dar es Salaam, Tanzania. Habitat International, 11, 133-145. https://doi.org/10.1016/0197-3975(87)90064-6

Brown, A. (2015). Topic Guide: Planning for Sustainable and Inclusive Cities in the Global South. Evidence on Demand. https://doi.org/10.12774/eod_tg.march2015.browna

Burra, M. M. (2004). Land Use Planning and Governance in Dar es Salaam: A Case Study from Tanzania. In K. T. Hansen, \& M. Vaa (Eds.), Reconsidering Informality, Perspectives from Urban Africa (pp. 143-147). Uppsala: The Nordic Africa Institute.

Burra, M. M. (2005). Community Initiatives in Land-Use Planning and Management of the Urban Environment. A Case Study of Makongo-Dar es Salaam City. Doctoral Thesis, Dar es Salaam: University of Dar es Salaam.

Cheshire, P., \& Vermuelen, W. (2009). Land Markets and Their Regulation: The Welfare Economics of Planning. LSE Research Online Version. http://eprints.lse.ac.uk/id/eprint/30787

Chiwambo, D. (2017). Analysis of the Factors Affecting Acceptability of Residential Licences in Tanzania. The Case of Ubungo Municipality. Master's Thesis, Dar es Salaam: Ardhi University.

De Soto, H. (2000). The Mystery of Capital: Why Capitalism Triumphs in the West and Fails Everywhere Else. New York: Basic Books.

Gwaleba, M. J. (2018). Urban Growth in Tanzania: Exploring Challenges, Opportunities and Management. International Journal of Social Science Studies, 6, 47-60. https://doi.org/10.11114/ijsss.v6i12.3783

Hove, M. (2013). The Urban Crisis in Sub-Saharan Africa: A Threat to Human Security and Sustainable Development. Stability, 2, 1-14. https://doi.org/10.5334/sta.ap

Kalugila, S. (2013). Housing Interventions and Its Influence on Urban Development: Opportunities and Challenges in Mixed Informal Settlements, in Dar es Salaam-Tanzania. Dissertation to Conferral of the Academic Degree Doctor of Philosophy, Weimar: The Faculty of Architecture of Bauhaus University.

Kironde, J. M. L. (1995). The Evolution of the Land Use Structure of Dar es Salaam: A Study into the Impacts of Land Policy. PhD Thesis, Nairobi: University of Nairobi.

Kironde, J. M. L. (2011). Makongo Juu Facelift: Some Food for Thought (p. 11). Sunday News May 29.

Kironde, J. M. L. (2015). Good Governance, Efficiency and the Provision of Planned Land for Orderly Development in African Cities: The Case of the 20,000 Planned Land Plots Project in Dar es Salaam, Tanzania. Current Urban Studies, 3, 348-367. https://doi.org/10.4236/cus.2015.34028

Kulaba, S. M. (1985). Managing Rapid Urban Growth through Sites and Services and Squatter Upgrading in Tanzania: Lessons of Experience. In P. Crooke (Ed.), Management of Sites and Services and Squatter Upgrading Housing Areas (pp. 31-42). Occasional Paper, Dar es Salaam: Centre for Housing Studies, Ardhi Institute.

Kusiluka, M. M., \& Chiwambo, D. M. (2018). Assessing Land Titles Application and Uptake in Regularised Informal Settlements in Tanzania. International Journal of Urban Sustainable Development, 10, 279-291. https://doi.org/10.1080/19463138.2018.1536661

Layson, J. P., \& Nankai, X. (2014). Integrating Community Participation in Urban Redevelopment Projects: The Case of Makongo in Dar es Salaam. Civil and Environmental Research, 6, 27-35.

Lerise, F. S., \& Silayo, E. (2017). Mainstreaming Good Land Governance in Settlement 
Formalization in Makongo Juu, Dar es Salaam City, Tanzania. CASLE Conference, Dar es Salaam, Tanzania, August, Unpublished.

Lupala, J., Malombe, J., \& Könye, A. (1997). Evaluation of Hanna Nassif Community-Based Urban Upgrading Project Phase I. Dar-es-Salaam: Government of Tanzania/UNDP/NIGP/Ford Foundation/ILO, Evaluation Mission Team Report.

Magigi, W., \& Majani, B. (2006). Community Involvement in Land Regularization for Informal Settlements in Tanzania: A Strategy for Enhancing Security of Tenure in Residential Neighborhoods. Habitat International, 30, 1066-1081.

https://doi.org/10.1016/j.habitatint.2005.12.002

Mazwile, M. (2013). Community Infrastructure Upgrading Project. https://locs4africa.iclei.org/wp-content/uploads/2013/11/Margareth-Mazwile-Commu nity-Infrastructure-Upgrading-Program.pdf

Michaels, G., Nigmatulina, D., Rauch, F., Regan, T., Baruah, N., \& Dahlstrand-Rudin, A. (2017). Planning Ahead for Better Neighborhoods. Long Run Evidence from Tanzania. Global Research Program on Spatial Development of Cities.

Moyo, K. (2006). The Perceptions of Security of Land Tenure in Informal Settlements in Tanzania: Findings from Dar es Salaam City. M.sc. Dissertation, Dar es Salaam: University of Dar es Salaam.

Payne, G., \& Majale, M. (2004). The Urban Housing Manual: Making Regulatory Frameworks Work for the Poor. Boca Raton, FL: CRC Press.

UN-Habitat (2008). State of the World s Cities Report. Nairobi: UN-Habitat.

UN-Habitat (2015). Informal Settlements (Habitat III Issue Paper 22). Nairobi: UN-Habitat.

UN-Habitat (2018). State of African Cities Report, 2018. Nairobi: UN-Habitat.

United Republic of Tanzania (URT) (1991). Makongo Juu Detailed Layout Plans of 1991. Dar es Salaam.

URT (1992). Economic Survey for the Year 1991. Dar es Salaam: National Planning Commission.

URT (1995). National Land Policy. Dar es Salaam: Government Printer.

URT (2000). National Human Settlements Development Policy, 2000. Dar es Salaam: Ministry of Lands, Housing and Human Settlements Development.

URT (2005). National Strategy for Growth and Poverty Reduction. Dar es Salaam: Ministry of Planning.

URT (2012a). National Programme for Regularization and Prevention of Unplanned Settlements 2012-2021. Dar es Salaam: Ministry of Lands.

URT (2012b). Makongo Juu Detailed Layout Plans. Dar es Salaam: Ministry of Lands.

URT (2013). Basic Facts and Figures on Human Settlements. Tanzania Mainland. Dar es Salaam: National Bureau of Statistics, Ministry of Finance. 